\title{
Erratum to: intensive inpatient treatment improves emotion-regulation capacities among adults with severe mental illness
}

J Christopher Fowler ${ }^{1,2^{*}}$, Jon G Allen ${ }^{1,2}$, John M Hart ${ }^{1}$, Hannah Szlyk ${ }^{1}$, Thomas E Ellis ${ }^{1,2}$, B Christopher Frueh ${ }^{1,2,3}$ and John M Oldham ${ }^{1,2}$

After publication of this research article [1], the authors noticed that the author name Hanna Szlykh should instead be stated as Hannah Szlyk.

\section{Competing interests}

The authors declare that they have no competing interests.

\section{Author details}

'The Menninger Clinic, 12301 Main Street, Houston, TX 77035, USA. ${ }^{2}$ Baylor College of Medicine, One Baylor Plaza, Houston, TX 77030, USA. ${ }^{3}$ Department of Psychology, University of Hawaii, 200 West Kawili St, Hilo, HI 96720, USA.

Received: 3 February 2015 Accepted: 9 February 2015

Published online: 20 March 2015

\section{Reference}

1. Fowler JC, Allen JG, Hart JM, Szlyk H, Ellis TE, Frueh BC, et al. Intensive inpatient treatment improves emotion-regulation capacities among adults with severe mental illness. Borderline Personality Disorder Emotion Dysregulation. 2014;1:19.

\footnotetext{
* Correspondence: cfowler@menninger.edu

${ }^{1}$ The Menninger Clinic, 12301 Main Street, Houston, TX 77035, USA

${ }^{2}$ Baylor College of Medicine, One Baylor Plaza, Houston, TX 77030, USA

Full list of author information is available at the end of the article
}

Submit your next manuscript to BioMed Central and take full advantage of:

- Convenient online submission

- Thorough peer review

- No space constraints or color figure charges

- Immediate publication on acceptance

- Inclusion in PubMed, CAS, Scopus and Google Scholar

- Research which is freely available for redistribution

Submit your manuscript at

www.biomedcentral.com/submit

( Biomed Central 